\title{
Impacts of green manure on crop yield, nitrogen leaching and nitrous oxide emissions in sandy and clay soil lysimeters
}

\author{
Kristiina Regina $^{1}$, Pooja Singh ${ }^{1,2}$ and Hannu Känkänen ${ }^{1}$ \\ ${ }^{1}$ Natural Resources Institute Finland (Luke), Tietotie 4, FI-31600, Jokioinen, Finland \\ ${ }^{2}$ Amity Institute of Environmental Sciences, Amity University, Amity University \\ Noida, U.P - 201301, India \\ e-mail: kristiina.regina@luke.fi
}

\begin{abstract}
We compared wheat yield, losses of nitrogen $(\mathrm{N})$ in leaching and gaseous losses as nitrous oxide $\left(\mathrm{N}_{2} \mathrm{O}\right)$ in silt and sand soil lysimeters. The studied cultivation systems were based on mineral fertilizer or mineral fertilizer together with clover green manure mulched at three different time points (August, October or May) before sowing of the main crop (either winter or spring wheat). Replacing $50-60 \%$ of mineral fertilizer $\mathrm{N}$ with green manure from a mixture of three clover species did not compromise crop yield of winter or spring wheat. The results suggest that mulching of the green manure in the spring succeeding its sowing is the most beneficial practice with respect to environmental impacts. Total $\mathrm{N}$ leaching was higher from sandy soil than from silt loam whereas emissions of $\mathrm{N}_{2} \mathrm{O}$ were higher from the silt soil. Residual $\mathrm{N}$ from the clover biomass did not lead to an increase in leaching losses of $\mathrm{N}$ during the growing season or one year from the harvest. However, the residual $\mathrm{N}$ can be a source of high $\mathrm{N}_{2} \mathrm{O}$ emissions during the winter period in boreal climatic conditions.
\end{abstract}

Key words: cover crop, fertilizer, nutrient management, cereal, clover

\section{Introduction}

Agricultural soils are a significant source of the greenhouse gas nitrous oxide $\left(\mathrm{N}_{2} \mathrm{O}\right)$ and eutrophication of watercourses. Half of the greenhouse gas emissions from agriculture and half of the nitrogen $(\mathrm{N})$ load to surface waters originate from agricultural soils (Statistics Finland 2020, Uusitalo et al. 2007). Improving nutrient management in crop production is a key factor in reducing these losses since all $\mathrm{N}$ not bound to living organisms is available for the processes causing gaseous or leaching losses.

Mineral fertilizers are the most common and readily available source of $\mathrm{N}$ for crops. Mineral fertilizers add greenhouse gas emission load to the carbon footprint of products (Heusala et al. 2020) and they do not maintain soil carbon stocks like organic fertilizers (Sanden et al. 2018). An option to replace part or all mineral fertilizer is to use green manure, i.e. plant material additional to the main crop, that releases nutrients for the main crop while its biomass decomposes. Crop residues from nitrogen-fixing plants grown as cover crops or green fallow preceding the main crop are considered especially sustainable N sources (Guardia et al. 2019, Sarauskis et al. 2019). Additional benefits of the extra biomass are the carbon input it brings to the soil (Poeplau and Don 2015) and multiple other ecosystem services like reduction of erosion and improved soil structure and microbial activity (BlancoCanqui et al. 2015).

The challenges in developing sustainable production chains in the climatic conditions of northern Europe are largely related to the short growing season in arable cropping leaving the soil bare for most of the year. It increases both the annual nutrient losses (Tattari et al. 2017) and $\mathrm{N}_{2} \mathrm{O}$ emissions (Regina et al. 2013) compared to perennial cropping. Cover crops can shorten the period of bare soil especially when mulching is scheduled as late as possible.

Green manure can provide yields comparable to mineral fertilizers (Tonitto et al. 2006, Blanco-Canqui et al. 2015). It has also been shown that green manure improves the yield and yield stability in organic agriculture (Knapp et al. 2018). However, challenges may turn up as $N$ from organic fertilizers is not readily available for the crop right after mulching and among other things the right timing of mulching defines the efficiency of nutrient use by the crop and thus both crop production potential and environmental losses (Ball et al. 2007, Abdalla et al. 2019).

Green manuring methods are variable and practical advice is needed to encourage farmers to adopt the methods with the most favourable environmental impact. The main aims of this study were 1) to estimate the potential to reduce mineral fertilizer use by clover mixture green manure and 2) to find the best timing for the mulching 
of the green manure from clover biomass in boreal conditions with respect to cereal yield and losses of $\mathrm{N}$ to the watercourses and the atmosphere. We hypothesized that mulching in October or in the spring succeeding the green manure sowing provides the most $\mathrm{N}$ input via the legume biomass and mulching in spring comes with the lowest environmental impacts.

\section{Materials and methods}

An experiment with three different green manure treatments and respective mineral fertilizer treatments was established on two soil types (silt and sand) in lysimeters in spring 2013. The experiment was conducted in a lysimeter field located in Jokioinen, south-western Finland $\left(60^{\circ} 81^{\prime} \mathrm{N}, 23^{\circ} 48^{\prime} \mathrm{E}\right)$. The average annual temperature in the area is $4.6^{\circ} \mathrm{C}$ and annual precipitation is $627 \mathrm{~mm}$ (Pirinen et al. 2012). The lysimeter field was established in 1981 and is described in detail in Jaakkola (1984) and Lemola et al. (2000). Content of organic carbon in the 0-20 cm layer was $2.3 \%$ in both soil types (Lemola and Turtola 2006). The $\mathrm{pH}$ of the soils ranged from 5.6 to 5.7. The proportions of soil particle size classes <2, 2-20, 20-60 and 60-200 $\mu \mathrm{m}$ were 17, 62, 14 and 3\% in the silt soil and 13, 8, 16 and $42 \%$ in the sandy soil, respectively. Details for the properties of the deeper soil layers are found in Lemola et al. (2000). The precipitation and mean daily air temperature data were obtained from a weather station of Finnish Meteorological Institute located approximately $1 \mathrm{~km}$ from the lysimeters.

A total of 36 lysimeters ( 4 replicates per treatment) arranged in two blocks were included in a split-plot design for studying the effects of green manure based cultivation on crop yield, gaseous emissions and nutrient leaching in silt and sandy soil. There were 8 additional lysimeters for determining the biomass yield. Mixture of red clover (Trifolium pratense L.), Persian clover (Trifolium resupinatum L.) and white clover (Trifolium repens L.) was used as green manure fertilizer for a wheat crop. Seeding rates were 5,4 and $3 \mathrm{~kg} \mathrm{ha}^{-1}$ for the red clover, Persian clover and white clover, respectively. The clover mixture was sown in May 2013 in the lysimeters with green manure treatment (Fig. 1., Table 1). Spring barley (Hordeum vulgare L.) was sown the same time in the lysimeters that represented the mineral fertilizer (MF) treatment. The clover was harvested in July 2013, corresponding to a normal field practice. Cutting height was $15 \mathrm{~cm}$, and the cut part of the crop was left on soil. The clover biomass (green manure; GM) was mulched to the soil either in August (GM1), in October (GM2) or the following spring 2014 (GM3). Winter wheat was sown in August 2013 in treatments GM1 and MF1 while spring wheat was sown in May 2014 in the other treatments.

The lysimeters had not been under active cultivation for several years before the experiment, and thus the preceding use represented extensive grassland. The mixed vegetation was removed and the soil was properly tilled just before this experiment. Before sowing the cereals, the soil was tilled and harrowed using hand tools. When the biomass was mulched it was gently mixed with the 10-15 cm layer of the topsoil.

\begin{tabular}{|c|c|c|c|c|c|c|}
\hline & $\begin{array}{l}2013 \\
\text { May }\end{array}$ & July & Aug & Oct & $\begin{array}{l}2014 \\
\text { May }\end{array}$ & Aug \\
\hline $\begin{array}{l}\text { MF1: mineral } \\
\text { fertiliser, } \\
\text { winter wheat }\end{array}$ & Sow barley & & $\begin{array}{c}\text { Harvest, } \\
\text { mulch straw, } \\
\text { sow wheat }\end{array}$ & & & Harvest \\
\hline $\begin{array}{l}\text { fertiliser, } \\
\text { spring wheat }\end{array}$ & Sow barley & & Harvest & Mulch straw & Sow wheat & Harvest \\
\hline $\begin{array}{l}\text { MF3: mineral } \\
\text { fertiliser, } \\
\text { spring wheat }\end{array}$ & Sow barley & & Harvest & & $\begin{array}{l}\text { Mulch straw, } \\
\text { sow wheat }\end{array}$ & Harvest \\
\hline $\begin{array}{l}\text { GM1: green } \\
\text { manure, } \\
\text { winter wheat }\end{array}$ & Sow clover & Cut clover & $\begin{array}{l}\text { Mulch } \\
\text { clover, sow } \\
\text { wheat }\end{array}$ & & & Harvest \\
\hline $\begin{array}{c}\text { GM2: green } \\
\text { manure, } \\
\text { spring wheat }\end{array}$ & Sow clover & Cut clover & & $\begin{array}{l}\text { Mulch } \\
\text { clover }\end{array}$ & Sow wheat & Harvest \\
\hline $\begin{array}{c}\text { GM3: green } \\
\text { manure, } \\
\text { spring wheat }\end{array}$ & Sow clover & Cut clover & & & $\begin{array}{l}\text { Mulch } \\
\text { clover, sow } \\
\text { wheat }\end{array}$ & Harvest \\
\hline
\end{tabular}

Fig. 1. Timeline of the experiment 
Table 1. Management of the experiment

\begin{tabular}{|c|c|c|c|c|c|c|}
\hline & MF1 & MF2 & MF3 & GM1 & GM2 & GM3 \\
\hline $\begin{array}{l}\text { Sowing of clover/ } \\
\text { barley }\end{array}$ & $\begin{array}{c}\text { Barley } \\
6 \text { May } 2013\end{array}$ & $\begin{array}{c}\text { Barley } \\
6 \text { May } 2013\end{array}$ & $\begin{array}{c}\text { Barley } \\
6 \text { May } 20134\end{array}$ & $\begin{array}{c}\text { Clover } \\
6 \text { May } 2013\end{array}$ & $\begin{array}{c}\text { Clover } \\
6 \text { May } 2013\end{array}$ & $\begin{array}{c}\text { Clover } \\
6 \text { May } 2013\end{array}$ \\
\hline $\begin{array}{l}\text { Cutting of clover/ } \\
\text { barley }\end{array}$ & 5 Aug 2013 & 5 Aug 2013 & 5 Aug 2013 & 15 July 2013 & 15 July 2013 & 15 July 2013 \\
\hline $\begin{array}{l}\text { Mulching of barley } \\
\text { straw/clover }\end{array}$ & 20 Aug 2013 & 8 Oct 2013 & 6 May 2014 & 20 Aug 2013 & 8 Oct 2013 & 6 May 2014 \\
\hline Sowing of wheat & 23 Aug $2013^{1}$ & 7 May 2014 & 7 May 2014 & 23 Aug $2013^{1}$ & 7 May 2014 & 7 May 2014 \\
\hline Fertilizer kg (N) ha-1 & $\begin{array}{c}80 \\
\text { (6 May 2013) } \\
30 \\
\text { (23 Aug 2013) } \\
100 \\
\text { (17 April 2014) } \\
20 \\
\text { (8 June 2014) }\end{array}$ & $\begin{array}{c}80 \\
(6 \text { May 2013) } \\
100 \\
\text { (7 May 2014) }\end{array}$ & $\begin{array}{c}80 \\
\text { (6 May 2013) } \\
100 \\
\text { (7 May 2014) }\end{array}$ & $\begin{array}{c}65 \\
\text { (17 April 2014) }\end{array}$ & $\begin{array}{c}50 \\
\text { (7 May 2014) }\end{array}$ & $\begin{array}{c}50 \\
\text { (7 May 2014) }\end{array}$ \\
\hline Harvest & 13 Aug 2014 & 21 Aug 2014 & 21 Aug 2014 & 13 Aug 2014 & 21 Aug 2014 & 21 Aug 2014 \\
\hline
\end{tabular}

$\mathrm{MF}=$ mineral fertilizer; $\mathrm{GM}=$ green manure; ${ }^{1} \mathrm{After}$ poor wintering of winter wheat, varying amounts of additional spring wheat seeds were sown in May 2014 in order to reach similar plant density in each lysimeter.

Above ground biomass yield of the clover was measured from two lysimeters that were not used in the other measurements in July 2013. Clover biomass was also weighed at each mulching event and returned to soil fresh and chopped. Grain and straw yield of all lysimeters were measured at harvest, on 13 August 2014 for the winter wheat and on 21 August 2014 for the spring wheat.

The emissions of $\mathrm{N}_{2} \mathrm{O}$ were measured 1-4 times per month, a total of 28 samplings between May 2013 and May 2014. Measurements were not done in the winter if there was the risk of disturbing the snow cover that would lead to biased results on leaching. A round chamber $(\varnothing 0.3 \mathrm{~m}$, height $0.6 \mathrm{~m})$ with a $10 \mathrm{~cm}$ high rubber ring as the lower edge was attached on a base cylinder (height $0.3 \mathrm{~m}$; installed to $10 \mathrm{~cm}$ depth) in each lysimeter and tightened with a hose clamp. Four gas samples $(20 \mathrm{ml}$ at 0, 10, 20, $30 \mathrm{~min}$ ) were taken by using a plastic syringe during a 30-minute chamber enclosure through a perforated PTFE tube inside the chamber as a sampling probe. Gas samples were immediately transferred to pre-evacuated Exetainer glass vials (Labco Ltd., High Wycombe, UK) and taken to the laboratory. Samples were analyzed gas chromatographically (HP 7890 Series, GC System, Hewlett Packard, USA) using an electron capture detector for $\mathrm{N}_{2} \mathrm{O}$ analysis (Kanerva et al. 2007). The observed increase of the gas concentration in the chamber was used to calculate the gas flux per area and time for each treatment. Cumulative annual fluxes for each treatment were calculated by linear interpolation of the daily flux rates between the measurement dates.

Leaching of $\mathrm{N}$ was studied by weighing the water that percolated through the soil profile under each lysimeter and analyzing the $\mathrm{N}$ content of a subsample from each water sampling. The concentrations of nitrate, ammonium and total nitrogen were determined using a colorimetric method (QuickChem AE, LachatInstruments, Loveland, CO, USA).

The statistical differences between the treatments were studied using the mixed model REML estimation method of SAS EG software (version 7.1). Treatment, soil type and sowing time (winter/spring wheat) as well as their twofactor interactions were added as fixed effects in the models. Block was added as a random effect. The degrees of freedom were computed by the Kenward-Roger method. Pairwise comparisons were done using the TukeyKramer method. The results of $\mathrm{N}_{2} \mathrm{O}$ were In-transformed and those of leaching log-transformed before the analysis to obtain a normal distribution.

\section{Results \\ Grain yields}

Grain yields varied between 2700-3900 kg per hectare and they did not differ statistically between treatments (Table 2). The $\mathrm{N}$ content of the grains was lower in the winter wheat treatments compared to spring wheat treatments in the silt soil. Grain N did not differ statistically between the treatments in the sandy soil. There were no consistent differences in the $\mathrm{N}$ content of the grains between soil types. 
Table 2. Crop grain yield and $\mathrm{N}$ content of the grains ( \pm standard deviation; $n=3$ or 4 )

\begin{tabular}{ccccc}
\hline & \multicolumn{2}{c}{ Grain yield $\left(\mathrm{kg} \mathrm{ha}^{-1}\right)$} & \multicolumn{2}{c}{ N content (\%) } \\
\hline Treatment & Silt & Sand & Silt & Sand \\
MF1 & $3860 \pm 419$ & $2770 \pm 806$ & $1.76 \pm 0.12^{\mathrm{a}}$ & $2.03 \pm 0.18$ \\
MF2 & $2960 \pm 195$ & $3000 \pm 652$ & $2.27 \pm 0.04^{\text {bcd }}$ & $2.18 \pm 0.15$ \\
MF3 & $2730 \pm 121$ & $2960 \pm 22.8$ & $2.33 \pm 0.11^{\mathrm{c}}$ & $2.05 \pm 0.02$ \\
GM1 & $3770 \pm 385$ & $2650 \pm 795$ & $1.96 \pm 0.19^{\text {ad }}$ & $2.27 \pm 0.19$ \\
GM2 & $2720 \pm 459$ & $3250 \pm 123$ & $2.44 \pm 0.10^{\mathrm{c}}$ & $2.32 \pm 0.08$ \\
GM3 & $2820 \pm 117$ & $3190 \pm 428$ & $2.45 \pm 0.16^{\mathrm{c}}$ & $2.30 \pm 0.16$ \\
\hline
\end{tabular}

MF1=mineral fertilizer + winter wheat, MF2=mineral fertilizer + spring wheat (straw mulching in autumn), MF3=mineral fertilizer + spring wheat (straw mulching in spring), GM1=green manure mulched in August + winter wheat, GM2=green manure mulched in October + spring wheat, GM3=green manure mulched in spring + spring wheat. Different letters denote statistical differences between the treatments within one soil type.

\section{Nitrogen leaching}

Over the monitoring period and across the treatments, $58 \%$ of the total leached $\mathrm{N}$ was nitrate, $17 \%$ was ammonium and the rest was either nitrite (not measured) or organic $\mathrm{N}$. We present only the results for the total $\mathrm{N}$ leaching. Annual leaching losses during the period of one year after sowing varied between $0.7-10 \mathrm{~kg} N$ per hectare (Table 3). Leaching of total $\mathrm{N}$ differed between the soil types; it was remarkably higher from the sandy soil $(p<0.001)$. Within both soil types, only the treatments with the lowest and highest values differed statistically. There were no consistent differences with respect to mineral or organic fertilizer even when tested for the whole two-year period (results not shown). Leaching of $\mathrm{N}$ was generally higher from the winter wheat than spring wheat treatments during winter 2014 (Fig. 2). The treatments with either bare soil (MF2, MF3) or clover biomass without the main crop (GM2, GM3) had moderate leaching losses during the first winter except for MF2 in sandy soil where the amount of leached $\mathrm{N}$ was as high as in the treatments with sowing in the preceding August. The legacy effect of the treatments after the last harvest had a similar pattern in both soil types; the leaching losses were the highest in MF1 and the lowest in MF3 and GM3 in spring 2015 (Fig. 2).

Table 3. Annual $\mathrm{N}$ input (fertilizer + clover residues) and output (grain + leaching) ( \pm standard deviation) and their sum $\left(\mathrm{kg} \mathrm{ha}^{-1}\right)$ in lysimeters fertilized with mineral fertilizer (MF) or green manure (GM)

\begin{tabular}{|c|c|c|c|c|c|c|c|}
\hline Soil & Treatment & Fertilizer & $\begin{array}{l}\text { Clover crop } \\
\text { residues }^{1}\end{array}$ & Grain & Leaching ${ }^{2}$ & $\mathrm{~N}_{2} \mathrm{O}$ & Total \\
\hline \multirow[t]{6}{*}{ Silt } & MF1 & 150 & 23 & $85 \pm 11$ & $1.73 \pm 0.73^{\mathrm{ab}}$ & $3.28 \pm 1.80^{\mathrm{ac}}$ & 83 \\
\hline & MF2 & 100 & 23 & $67 \pm 5.5$ & $1.48 \pm 0.94^{\mathrm{ab}}$ & $6.66 \pm 7.10^{\mathrm{ac}}$ & 48 \\
\hline & MF3 & 100 & 23 & $64 \pm 3.4$ & $0.74 \pm 0.50^{\mathrm{a}}$ & $2.77 \pm 1.37^{\mathrm{ac}}$ & 55 \\
\hline & GM1 & 65 & 184 & $93 \pm 9.2$ & $0.98 \pm 0.33^{\mathrm{ab}}$ & $14.1 \pm 9.00^{b}$ & 141 \\
\hline & GM2 & 50 & 166 & $66 \pm 11$ & $2.20 \pm 1.45^{b}$ & $7.51 \pm 5.75^{\mathrm{ab}}$ & 140 \\
\hline & GM3 & 50 & 125 & $69 \pm 7.2$ & $1.52 \pm 0.86^{\mathrm{ab}}$ & $1.84 \pm 0.83^{c}$ & 103 \\
\hline \multirow[t]{6}{*}{ Sand } & MF1 & 150 & 17 & $72 \pm 24$ & $3.67 \pm 1.04^{\mathrm{a}}$ & $1.20 \pm 0.74^{\mathrm{ab}}$ & 90 \\
\hline & MF2 & 100 & 17 & $65 \pm 10$ & $8.91 \pm 4.02^{\mathrm{ab}}$ & $1.18 \pm 0.84^{\mathrm{ab}}$ & 42 \\
\hline & MF3 & 100 & 17 & $61 \pm 0.7$ & $7.90 \pm 2.60^{\mathrm{ab}}$ & $0.74 \pm 0.26^{\mathrm{a}}$ & 47 \\
\hline & GM1 & 65 & 129 & $77 \pm 19$ & $4.41 \pm 1.73^{\mathrm{ab}}$ & $0.99 \pm 0.12^{\mathrm{ab}}$ & 112 \\
\hline & GM2 & 50 & 166 & $75 \pm 1.5$ & $10.3 \pm 4.01^{b}$ & $2.17 \pm 0.12^{b}$ & 129 \\
\hline & GM3 & 50 & 101 & $73 \pm 5.2$ & $6.83 \pm 1.68^{\mathrm{ab}}$ & $1.35 \pm 0.20^{\mathrm{ab}}$ & 70 \\
\hline
\end{tabular}

${ }^{1}$ Above ground biomass; ${ }^{2}$ The reported period is one year from wheat sowing, i.e. it starts in May 2014 for other treatments but August 2013 for MF1 and GM1. MF1=mineral fertilizer + winter wheat; MF2=mineral fertilizer + spring wheat (straw mulching in autumn); MF3=mineral fertilizer + spring wheat (straw mulching in spring); GM1=green manure mulched in August + winter wheat; GM2=green manure mulched in October + spring wheat; GM3=green manure mulched in spring + spring wheat. Different letters denote statistical differences between the treatments within one soil type. 


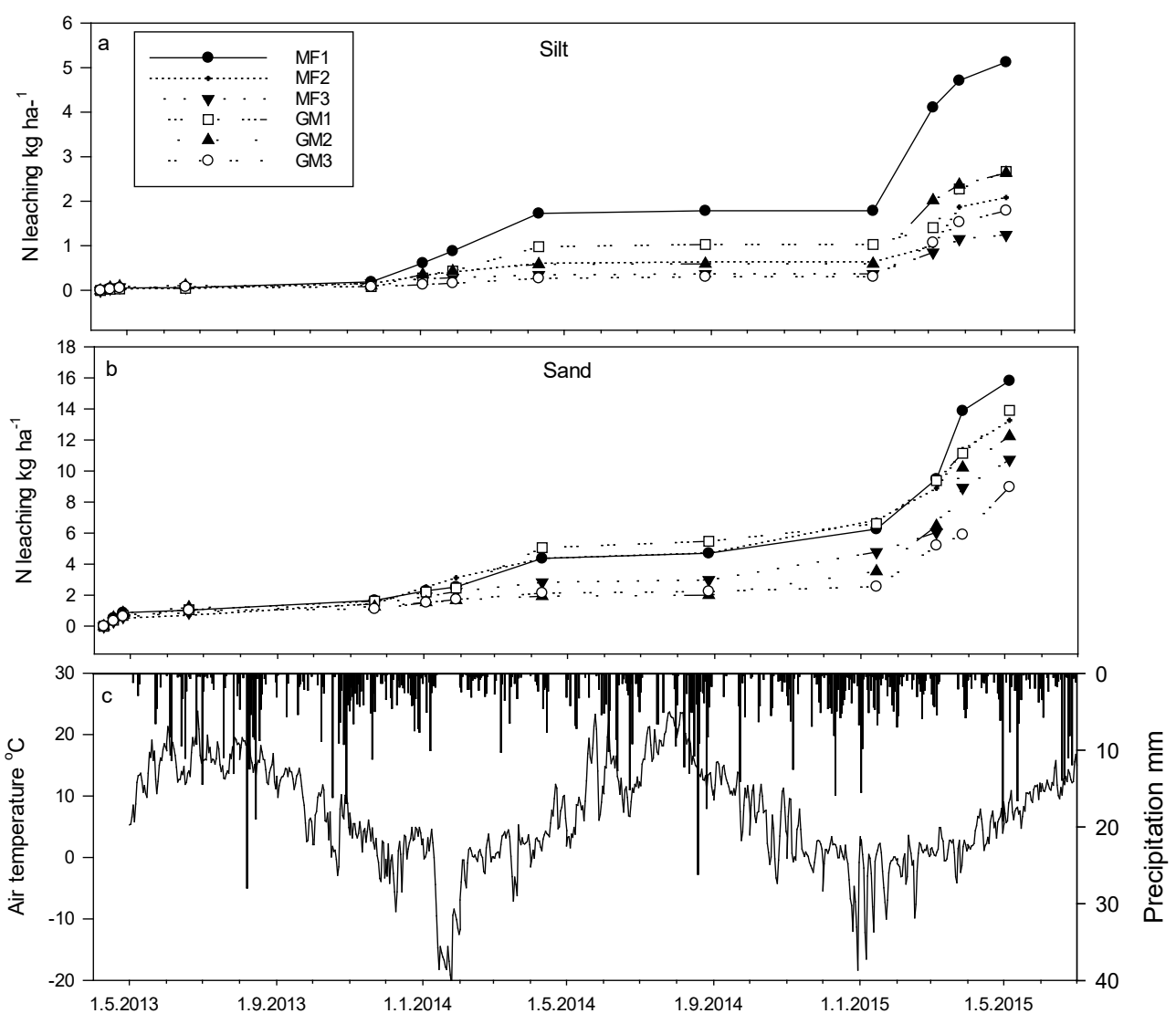

Fig. 2. Cumulative leaching of total $N$ from different green manure or fertilizer treatments $(n=4)$ on a) silt soil and b) sandy soil. MF1=mineral fertilizer + winter wheat, MF2=mineral fertilizer + spring wheat (straw mulching in autumn), MF3=mineral fertilizer + spring wheat (straw mulching in spring), GM1=green manure mulched in August + winter wheat, GM2=green manure mulched in October + spring wheat, GM3=green manure mulched in spring + spring wheat. Note different scales of the $y$-axis for the soil types.

\section{Nitrous oxide emissions}

The emission rate of $\mathrm{N}_{2} \mathrm{O}$ remained low for some weeks after the establishment of the experiment and the first $\mathrm{N}_{2} \mathrm{O}$ peak appeared in June 2013 after the first rain event after sowing of barley or clover (Fig. 3). The peak was high in all treatments and higher in the silt than in the sandy soil. The cutting of the clover biomass in July 2013 did not increase the direct emissions during the summer. Sowing of winter wheat in MF1 and GM1 in August 2013 did not cause any increase in $\mathrm{N}_{2} \mathrm{O}$ emissions in the silty soil (Fig. 3a) but a slight enhancement was observed in the sandy soil (Fig. 3c). The measurements during the winter season showed that the period of snowmelt in March induced emission peaks of the same magnitude as those induced by sowing and rainfall in the spring. The fluxes of $\mathrm{N}_{2} \mathrm{O}$ were generally higher from silt than from sandy soil $(p<0.001)$. The green manure treatments tended to have higher winter emissions than the mineral fertilized treatments. In the silt soil, the highest annual fluxes were found in the green manure treatment GM1 and the lowest in GM3 (Table 3). In the sandy soil, only the treatments with the lowest (MF3) and highest (GM2) emissions differed from each other statistically.

Sum of the measured inputs and outputs of $\mathrm{N}$ estimated for an area of one hectare showed excess of $\mathrm{N}$ in all treatments (Table 3). The net result was higher in the green manure than in the mineral fertilizer treatments with one exception: GM3 in the sandy soil where the clover biomass was weak (Table 3). The largest share of the excess $\mathrm{N}$ originated from the $\mathrm{N}$ input in fertilizer and green manure. $\mathrm{N}$ input in the aboveground biomass of the legume varied from 100 to $180 \mathrm{~kg} \mathrm{~N}^{-1}$ and together with the added mineral fertilizer the input of $\mathrm{N}$ was in total larger in the green manure treatments compared to the control treatments. 

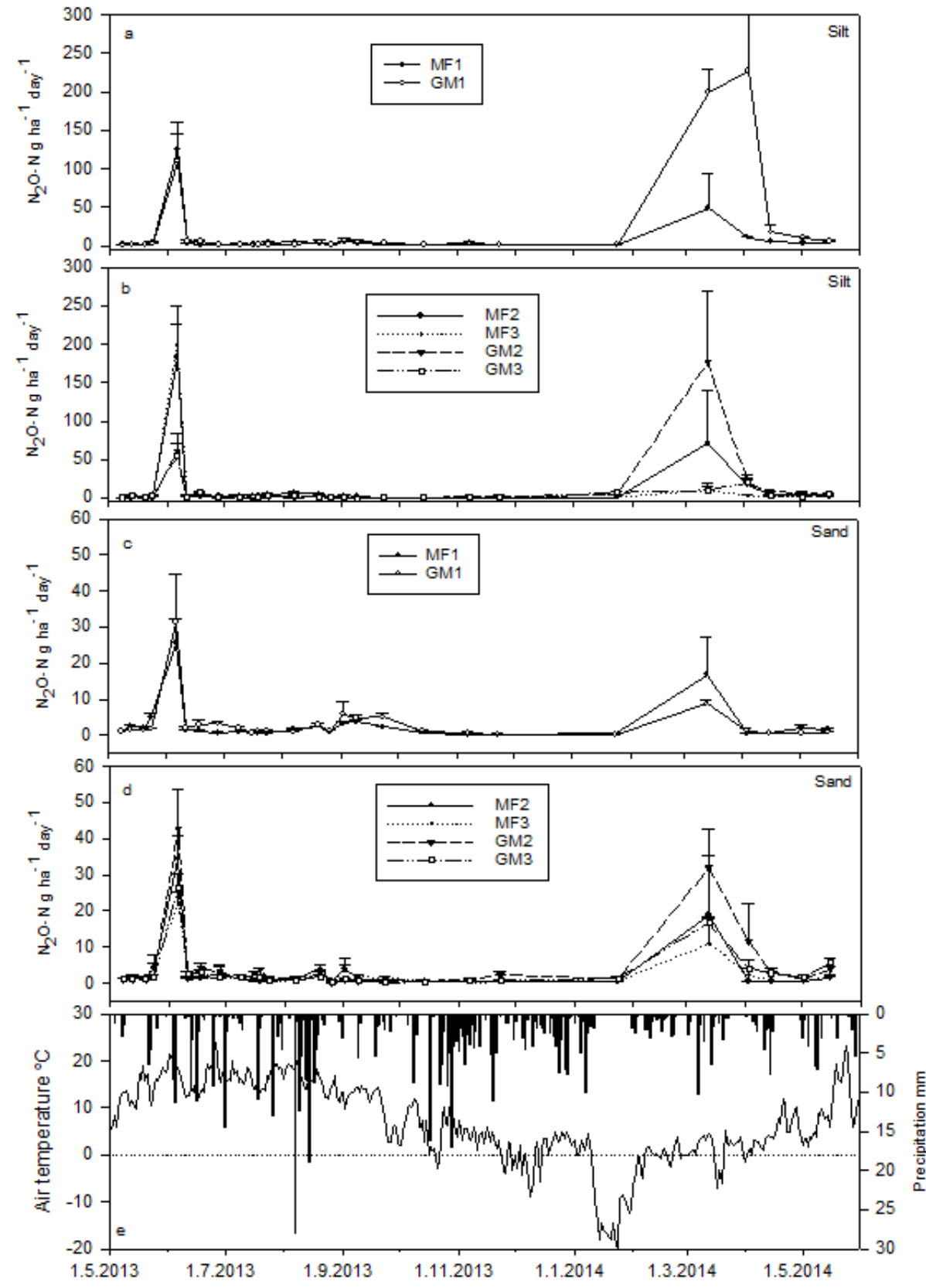

Fig. 3. Emissions of $\mathrm{N}_{2} \mathrm{O}$ ( \pm positive standard error) from different green manure or fertilizer treatments $(n=4)$ for winter wheat in silt soil (a) and sandy soil (c) and for spring wheat in silt soil b) and sandy soil (d) and daily temperature and precipitation (e). MF1=mineral fertilizer + winter wheat, MF2=mineral fertilizer + spring wheat (straw mulching in autumn), MF3=mineral fertilizer + spring wheat (straw mulching in spring), GM1=green manure mulched in August + winter wheat, GM2=green manure mulched in October + spring wheat, GM3=green manure mulched in spring + spring wheat. Note different scales of the $y$-axis for the soil types.

\section{Discussion}

In this experiment, crop yield of wheat was lower than the average of the region in 2014 which was 4200 and $4000 \mathrm{~kg} \mathrm{ha}^{-1}$ for winter and spring wheat, respectively (Luke 2020). Because the experimental setup did not limit the availability of radiation or rain the slightly hampered crop growth was likely due to shading of the crop by the frame of the gas measurement chamber or some minor damage to the plants by the greenhouse gas emission measurements. In the silt soil, the yield was higher in the winter wheat compared to spring wheat treatments but in the sandy soil it was vice versa. A general conclusion from the comparison of the treatments is that the yields are similar from mineral fertilizer and green manure fertilized crops suggesting that replacing part of mineral $\mathrm{N}$ with biomass-based $\mathrm{N}$ is a viable option not only in organic but also in conventional agriculture. 
This was also the general conclusion from a study of seven sites reporting that red clover was a good precrop in most trials (Känkänen et al. 1999). Also Tonitto et al. (2006) reported only neutral or positive yield impacts of plant biomass-based nutrient management.

As regards the timing of mulching, the treatments with clover mulching in October or May did not differ in their crop production and no clear recommendation on the timing can be given on the basis of crop yield prediction. Late mulching has been found to provide the best $\mathrm{N}$ supply for the crop and the best yield in previous studies in Finland (Känkänen et al. 1999, Lahti and Kuikman 2003).

As the grain yields in $\mathrm{GM}$ were similar to those in $\mathrm{MF}$, the reduction in $\mathrm{N}$ fertilizer application was well predicted in the research plan. The results suggest that the use of a clover mixture green manure can reduce $\mathrm{N}$ fertilizer use by 50 to $80 \mathrm{~kg} \mathrm{ha}^{-1}$ which is more than previously estimated for pure red clover and similar to the estimates for vetch green manure in the field trials by Känkänen et al. (1999).

There was a clear tendency towards higher grain protein content in the green manure treatments compared to their mineral fertilized counterparts. This suggests that some extra income from bread wheat could be an additional agronomic benefit of green manure management. An increase in the protein content of spring cereals due to leguminous pre-crops has also been found by e.g. Ingver et al. (2019) and Moyo et al. (2015). However, these positive economic impacts in green manure practice are partly counteracted by reduced income due to one year without a cash crop. An alternative to green manure is undersown cover crop which however leads to smaller fertilizer N replace value (Känkänen 2010). Nevertheless, it can be concluded that generally the use of clover cover crops reduces the profitability of using mineral $\mathrm{N}$ fertilizers (Bergkvist et al. 2010). Further, long-term positive effects on soil quality and productivity (Fageria 2009) should be taken into account when the economy of green manures and cover crops is evaluated.

Leaching of $\mathrm{N}$ was lower than the average rate of $15.5 \mathrm{~kg} \mathrm{ha}^{-1}$ in Finland in all treatments (Tattari et al. 2017) but this is understandable as the reported national rate is based on measurement of $\mathrm{N}$ losses of entire catchments which often include organic soils with relatively high nutrient losses. Emission rates of $\mathrm{N}_{2} \mathrm{O}$ were in the range of measured annual fluxes from mineral agricultural soils in Finland (Regina et al. 2013).

Losses of $\mathrm{N}$ in leaching were higher from the sandy soil compared to the silty soil which is most probably related to faster water infiltration rate in sandy soils (Beaudoin et al. 2005). On the contrary, silt soil had higher emissions of $\mathrm{N}_{2} \mathrm{O}$ compared to sandy soil likely due to more optimal conditions for denitrification in the less porous silty soil where anaerobic zones are easily developed (Bryk 2018, Rochette et al. 2018). Thus, it is probably not feasible to formulate solid recommendations on $\mathrm{N}$ management stratified by soil type.

In most cases, $\mathrm{N}_{2} \mathrm{O}$ emissions or leaching of $\mathrm{N}$ did not differ between the green manure treatments and their mineral $\mathrm{N}$ fertilized counterparts. This suggests that the legacy effect of green manure is not a remarkable concern with respect to $\mathrm{N}$ losses especially to watercourses. However, the results suggest that there can be a risk of high $\mathrm{N}_{2} \mathrm{O}$ emissions with green manure during the winter although our measurements were not frequent enough to make a reliable comparison during the wintertime.

Our evidence supports the view that late mulching is better with respect to losses of $\mathrm{N}$. In the case of $\mathrm{N}_{2} \mathrm{O}$, the winter-time peak was lower from GM3 than GM2 and the leaching rate remained lower in GM3 especially during the last months of the measurement period. Several authors have stressed that mulching during the cool period of the year reduces $\mathrm{N}$ losses to the environment (Korsaeth et al. 2002, Ball et al. 2007). Incorporation of the green manure improves the contact of the plant residue with the soil and enhances its mineralization. In boreal conditions, feasible times of mulching are October and May as the soil is frozen or too wet in between those. Initiation of mineralization in October may be too early from the viewpoint of efficient $\mathrm{N}$ management and incorporation in the spring may contain the risk of delay due to wet soil conditions.

Peaks of $\mathrm{N}_{2} \mathrm{O}$ are often not directly related to the $\mathrm{N}$ amendments. This was shown after the sowing of the first barley crop in 2013 when treatments MF1 and GM1 did not differ regardless that the former received $80 \mathrm{~kg}$ of mineral $\mathrm{N}$ in May and the latter none. Thus, the peak after sowing was apparently not only caused by fertilization but mainly by disturbance of the soil at sowing. During that period, the peaks in the non-fertilized green manure treatments were remarkably lower than those in the control treatments only in the case of GM2 and GM3 in silty soil. Similar peaks with no fertilization were observed in a Swiss study by Skinner et al. (2019). 
As more than half of the annual emissions of $\mathrm{N}_{2} \mathrm{O}$ in the northern Europe are typically released during the winter period (Regina et al. 2013) and the main part of leaching losses also occurs outside the growing period (Aronsson et al. 2016), it is clear that the amount of $\mathrm{N}$ in soil after harvest is crucial for the environmental impact of fertilizer strategies. The difference of the measured inputs and outputs was positive, ranging from 40 to $140 \mathrm{~kg} \mathrm{~N} \mathrm{ha}^{-1}$ in the different treatments, evidently enabling large losses to the atmosphere and watercourses. These values

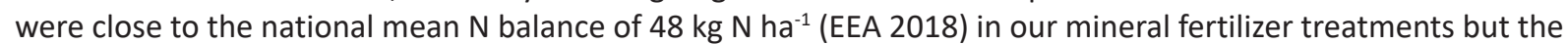
residual $\mathrm{N}$ of the clover clearly increased the net result in the green manure treatments. However, a high fraction of the excess $\mathrm{N}$ was in organic form. As the losses to water and air were not higher from the green manure treatments, it can be deduced that the residual clover $\mathrm{N}$ was not a remarkable source of these losses. The residual $\mathrm{N}$ in soil comprises as much as $30-40 \%$ of the plant uptake and thus is a relevant pool of nutrients in crop production not only during the first year but also in the subsequent years (Yan et al. 2020).

The amount of $\mathrm{N}$ in the above ground residues of clover was $100-180 \mathrm{~kg} \mathrm{ha}^{-1}$ which is low compared to the reported rates in northern Europe (Skuodiene et al. 2012, Brozyna et al. 2013) but in the upper range of typical Finnish observations (Känkänen et al. 1998). However, it is to be noted that $\mathrm{N}$ from roots and exudates was not included in our calculations. Their share can be as high as that of the above ground parts (Känkänen et al. 1998, Känkänen and Eriksson 2007, De Notaris et al. 2020). Moyo et al. 2015 concluded that the importance of red clover roots and nodules is high for the grain yield of the succeeding winter wheat. De Notaris et al. (2020) found that $39 \%$ of root $\mathrm{N}$ was mineralized in 118 days and according to Fontaine et al. (2020) cereals can take up about a half of the $\mathrm{N}$ of the root biomass of the previous crop. Thus, a considerable share of the mineralized $\mathrm{N}$ originated from the root biomass also in our study, and the amount of clover $\mathrm{N}$ remaining in the soil was relatively high.

Our green manure treatments received mineral fertilizer in addition to the $\mathrm{N}$ from the clover residues and thus they did not represent pure organic farming. This kind of practice is suitable especially for a conventional farmer wishing to reduce the environmental impact of his products as the share of fertilizer production in the carbon footprint of cereal production is in the range of 25-30\% (Heusala et al. 2020). Leguminous cover crop was rated an effective mitigation measure in life cycle analyses both in Mediterranean conditions (Guardia et al. 2019) and in Finland (Rasi et al. 2020).

This type of green manuring does not allow for producing a cash crop every year and this has implications on the need of the cultivated area if widely applied. Also, in Finnish climate, the $\mathrm{N}$ yield of the green manure is modest if sown after harvest. A compromise would be to grow the legume biomass undersown which also has its downsides like competition of the cover crop with the main crop. However, the grain yield decrease caused by undersown clovers can be considered small (Känkänen and Eriksson 2007) or nonexistent (Valkama et al. 2015). In order to improve the efficiency of green manure as a fertilizer, several authors have suggested harvest of the legume biomass and its return to soil after an anaerobic treatment and biogas production (Möller and Stinner 2009, Nadeem et al. 2012).

\section{Conclusions}

As the crop yield did not differ between treatments based on sole mineral $\mathrm{N}$ or combination of mineral and organic $\mathrm{N}$, replacing mineral fertilizer with green manure is a viable option in cereal production. The mulching time of the green manure did not affect the yield which leads to the conclusion that the mulching time should be decided on the basis of environmental rather than agronomic arguments. This study is in line with most previously published data suggesting that losses of $\mathrm{N}$ to the environment can be diminished by as late mulching time as possible when using green manure based fertilization. The proportion of leaching losses compared to gaseous losses differed between the studied soil types. Based on these results, leaching losses are of greater concern in coarse soils whereas losses as $\mathrm{N}_{2} \mathrm{O}$ are more significant in fine textured soils. However, minimizing the residual $\mathrm{N}$ after harvest is the best measure for diminishing both types of $\mathrm{N}$ losses and thus this is the most important message to convey to the farming community.

\section{Acknowledgements}

The authors are grateful to the technical staff of Luke for skillful work in the field and laboratory. P.S. acknowledges the Centre for International Mobility of the Ministry of Education and Culture of Finland for a mobility grant. 


\section{References}

Abdalla, M., Hastings, A., Cheng, K., Yue, Q., Chadwick, D., Espenberg, M., Truu, J., Rees, R.M. \& Smith, P. 2019. A critical review of the impacts of cover crops on nitrogen leaching, net greenhouse gas balance and crop productivity. Global Change Biology 25 : 2530-2543. https://doi.org/10.1111/gcb.14644

Aronsson, H., Hansen, E.M., Thomsen, I.K., Liu, J., Ogaard, A.F., Känkänen, H. \& Ulen, B. 2016. The ability of cover crops to reduce nitrogen and phosphorus losses from arable land in southern Scandinavia and Finland. Journal of Soil and Water Conservation 71: 41-55. https://doi.org/10.2489/jswc.71.1.41

Ball, B.C., Watson, C.A. \& Crichton, I. 2007. Nitrous oxide emissions, cereal growth, N recovery and soil nitrogen status after ploughing organically managed grass/clover swards. Soil Use Manage 23: 145-55. https://doi.org/10.1111/j.1475-2743.2006.00072.x

Bergkvist, G., Adler, A., Hansson, M. \& Weih, M. 2010. Red fescue undersown in winter wheat suppresses Elytrigia repens. Weed Research 50: 447-455. https://doi.org/10.1111/j.1365-3180.2010.00789.x

Blanco-Canqui, H., Shaver, T.M., Lindquist, J.L., Shapiro, C.A., Elmore, R.W., Francis, C.A. \& Hergert, G.W. 2015. Cover crops and ecosystem services: Insights from studies in temperate soils. Agronomy Journal 107: 2449-2474.https://doi.org/10.2134/agronj15.0086

Beaudoin, N., Saad, J.K., Van Laethem, C., Machet, J.M., Maucorps, J. \& Mary, B. 2005. Nitrate leaching in intensive agriculture in Northern France: Effect of farming practices, soils and crop rotations. Agriculture Ecosystems \& Environment 111: 292-310. https://doi.org/10.1016/j.agee.2005.06.006

Brozyna, M.A., Petersen, S.O., Chirinda, N. \& Olesen, J.E. 2013. Effects of grass-clover management and cover crops on nitrogen cycling and nitrous oxide emissions in a stockless organic crop rotation. Agriculture Ecosystems \& Environment 181:115-126. https://doi.org/10.1016/j.agee.2013.09.013

Bryk, M. 2018. Resolving compactness index of pores and solid phase elements in sandy and silt loamy soils. Geoderma 318 : 109-122. https://doi.org/10.1016/j.geoderma.2017.12.030

De Notaris, C., Olesen, J.E., Sörensen, P. \& Rasmussen, J. 2020. Input and mineralization of carbon and nitrogen in soil from legume-based cover crops. Nutrient Cycling in Agroecosystems 116: 1-18. https://doi.org/10.1007/s10705-019-10026-z

EEA 2018. Agricultural land - nitrogen balance. https://www.eea.europa.eu/airs/2018/natural-capital/agricultural-land-nitrogenbalance

Fageria, N.K. 2009. The use of nutrients in crop plants. Boca Raton: CRC Press. 430 p.

Fontaine, D., Eriksen, J. \& Sörensen, P. 2020. Cover crop and cereal straw management influence the residual nitrogen effect. European Journal of Agronomy 118: 126100. https://doi.org/10.1016/j.eja.2020.126100

Guardia, G., Aguilera, E., Vallejo, A., Sanz-Cobena, A., Alonso-Ayuso, M. \& Quemada, M. 2019. Effective climate change mitigation through cover cropping and integrated fertilization: A global warming potential assessment from a 10-year field experiment. Journal of Cleaner Production 241: 118307. https://doi.org/10.1016/j.jclepro.2019.118307

Heusala, H., Sinkko, T., Sözer, N., Hytönen, E., Mogensen, L. \& Trydeman Knudsen, M.T. 2020. Carbon footprint and land use of oat and faba bean protein concentrates using a life cycle assessment approach. Journal of Cleaner Production 242: 118376. https://doi.org/10.1016/j.jclepro.2019.118376

Ingver, A., Tamm, U., Tamm, I., Tamm, S., Tupits, I., Bender, A., Koppel, R., Narits, L. \& Koppel, M. 2019. Leguminous pre-crops improved quality of organic winter and spring cereals. Biological Agriculture \& Horticulture 35: 46-60. https://doi.org/10.1080/01448765.2018.1509728

Jaakkola, A. 1984. Leaching losses of nitrogen from a clay soil under grass and cereal crops in Finland. Plant Soil 76: 59-66. https://doi.org/10.1007/978-94-009-6101-2_5

Kanerva, T., Regina, K., Rämö, K., Ojanperä, K. \& Manninen, S. 2007. Fluxes of $\mathrm{N}_{2} \mathrm{O}, \mathrm{CH}_{4}$ and $\mathrm{CO}_{2}$ under a meadow ecosystem exposed to elevated $\mathrm{O}_{3}$ and $\mathrm{CO}_{2}$ for three years. Environmental Pollution 134: 818-828. https://doi.org/10.1016/j.envpol.2006.03.055

Knapp, S. \& van der Heijden, M.G.A. 2018. A global meta-analysis of yield stability in organic and conservation agriculture. Nature Communications 9: 3632. https://doi.org/10.1038/s41467-018-05956-1

Korsaeth, A., Henriksen, T. \& Bakken, L. 2002. Temporal changes in mineralization and immobilization of N during degradation of plant material: Implications for the plant N supply and nitrogen losses. Soil Biology \& Biochemistry 34: 789-799. https://doi.org/10.1016/S0038-0717(02)00008-1

Känkänen, H., Kangas, A., Mela, T., Nikunen, U., Tuuri, H. \& Vuorinen, M. 1999. The effect of incorporation time of different crops on the residual effect on spring cereals. Agricultural and Food Science in Finland 8: 285-298. https://doi.org/10.23986/afsci.5629

Känkänen, H., Kangas, A., Mela, T., Nikunen, U., Tuuri, H. \& Vuorinen, M. 1998. Timing incorporation of different green manure crops to minimize the risk of nitrogen leaching. Agricultural and Food Science in Finland 7:553-567. https://doi.org/10.23986/afsci.5613

Känkänen, H. \& Eriksson, C. 2007. Effects of undersown crops on soil mineral $\mathrm{N}$ and grain yield of spring barley. European Journal of Agronomy 27: 25-34. https://doi.org/10.1016/j.eja.2007.01.010

Känkänen, H. 2010. Undersowing in a northern climate: effects on spring cereal yield and risk of nitrate leaching. MTT Science, MTT Tiede 8: 93 p. Doctoral Dissertation.

Lahti, T. \& Kuikman, P.J. 2003. The effect of delaying autumn incorporation of green manure crop on $\mathrm{N}$ mineralization and spring wheat (Triticum aestivum L.) performance. Nutrient Cycling in Agroecosystems 65: 265-280. https://doi.org/10.1023/A:1022617104296

Lemola, R., Turtola, E. \& Eriksson, C. 2000. Undersowing Italian ryegrass diminishes nitrogen leaching from spring barley. Agricultural and Food Science in Finland 9: 201-215. https://doi.org/10.23986/afsci.5661 
Lemola, R. \& Turtola, E. 2006. Typen huuhtoutuminen laitumelta eri maalajeilla. In: Virkajärvi \& Uusi-Kämppä, eds. Laitumen ja suojavyöhykkeiden ravinnekierto ja ympäristökuormitus. Maa- ja elintarviketalous 76. 208 p. (in Finnish). http://urn.fi/ URN:ISBN:951-729-999-0

Luke 2020. Statistics database of Natural Resources Institute Finland. http://statdb.luke.fi/PXWeb/pxweb/en/LUKE/?rxid=dc711a9ede6d-454b-82c2-74ff79a3a5e0

Moyo, H., Davies, W.P., Cannon, N.D. \& Conway, J.S. 2015. Influences of one-year red clover ley management on subsequent cereal crops. Biological Agriculture \& Horticulture 31: 193-204. https://doi.org/10.1080/01448765.2014.1001792

Möller, K. \& Stinner, W. 2009. Effects of different manuring systems with and without biogas digestion on soil mineral nitrogen content and on gaseous nitrogen losses (ammonia, nitrous oxides). European Journal of Agronomy 30: 1-16. https://doi.org/10.1016/j.eja.2008.06.003

Nadeem, S., Hansen, S., Bleken, M.A. \& Dörsch, P. 2012. N2O emission from organic barley cultivation as affected by green manure management. Biogeosciences 9: 2747-2759. https://doi.org/10.5194/bg-9-2747-2012

Pirinen, P., Simola, H., Aalto, J., Kaukoranta, J.-P., Karlsson, P. \& Ruuhela, R. 2012. Tilastoja Suomen ilmastosta 1981 - 2010. Reports of Finnish Meteorological Institute 2012:1. 96 p. http://hdl.handle.net/10138/35880

Poeplau, C. \& Don, A. 2015. Carbon sequestration in agricultural soils via cultivation of cover crops - A meta-analysis. Agriculture Ecosystems \& Environment 200: 33-41. https://doi.org/10.1016/j.agee.2014.10.024

Rasi, S., Timonen, K., Joensuu, K., Regina, K., Virkajärvi, P., Heusala, H., Tampio, E. \& Luostarinen, S. 2020. Sustainability of vehicle fuel biomethane produced from grass silage in finland. Sustainability 12: 3994. https://doi.org/10.3390/su12103994

Rochette, P., Liang, C., Pelster, D., Bergeron, O., Lemke, R., Kroebel, R., MacDonald, D., Yan, W. \& Flemming, C. 2018. Soil nitrous oxide emissions from agricultural soils in Canada: Exploring relationships with soil, crop and climatic variables. Agriculture Ecosystems \& Environment 254: 69-81. https://doi.org/10.1016/j.agee.2017.10.021

Regina, K., Kaseva, J. \& Esala, M. 2013. Emissions of nitrous oxide from boreal agricultural mineral soils - Statistical models based on measurements. Agriculture Ecosystems \& Environment 164: 131-136. https://doi.org/10.1016/j.agee.2012.09.013

Sanden, T., Spiegen, H., Stuger, H., Schlattern, N., Haslmayr, H., Zavattaro, L., Grignani, C., Bechini, L., D’Hose, T., Molendijk, L., Pecio, A., Jarosz, Z., Guzmán, G., Vanderlinden, K., Giráldez, J.V., Mallast, J. \& ten Berge, H. 2018. European long-term field experiments: knowledge gained about alternative management practices. Soil Use and Management 34: 167-76. https://doi.org/10.1111/sum.12421

Sarauskis, E., Masilionyte, L., Juknevicius, D., Buragiene, S. \& Kriauciuniene, Z. 2019. Energy use efficiency, GHG emissions, and cost-effectiveness of organic and sustainable fertilisation. Energy 172: 1151-1160. https://doi.org/10.1016/j.energy.2019.02.067

Skinner, C., Gattinger, A., Krauss, M., Krause, H., Mayer, J., van der Heijden, M.G.A. \& Mader, P. 2019. The impact of long-term organic farming on soil-derived greenhouse gas emissions. Scientific Reports 9: 1702. https://doi.org/10.1038/s41598-018-38207-w

Skuodiene, R., Nekrosiene, R. \& Repsiene, R. 2012. Residual effects of perennial grasses as green manure on soil agrochemical properties and spring barley. Zemdirbyste-Agriculture 99: 237-246.

Statistics Finland 2020. Greenhouse Gas Emissions in Finland 1990-2018. National Inventory Report Under the UNFCCC and the Kyoto Protocol, 2020. http://www.stat.fi/tup/khkinv/khkaasut_raportointi_en.html

Tattari, S., Koskiaho, J., Kosunen, M., Lepistö, A., Linjama, J. \& Puustinen, M. 2017. Nutrient loads from agricultural and forested areas in Finland from 1981 up to 2010 - can the efficiency of undertaken water protection measures seen? Environmental Monitoring and Assessment 189: 189:95. https://doi.org/10.1007/s10661-017-5791-z

Tonitto, C., David, M. \& Drinkwater, L. 2006. Replacing bare fallows with cover crops in fertilizer-intensive cropping systems: A meta-analysis of crop yield and N dynamics. Agriculture Ecosystems \& Environment 112: 58-72. https://doi.org/10.1016/j.agee.2005.07.003

Uusitalo, R., Turtola, E., Grönroos, J., Kivistö, J., Mäntylahti, V., Turtola, A., Lemola, R. \& Salo, T. 2007. Finnish trends in phosphorus balances and soil test phosphorus. Agricultural and Food Science 16: 301-316. https://doi.org/10.2137/145960607784125339

Valkama, E., Lemola, R., Känkänen, H. \& Turtola, E. 2015. Meta-analysis of the effects of undersown catch crops on nitrogen leaching loss and grain yields in the Nordic countries. Agriculture, Ecosystems and Environment 203: 93-101. https://doi.org/10.1016/j.agee.2015.01.023

Yan, M., Pan, G., Lavallee, J.M. \& Conant, R.T. 2020. Rethinking sources of nitrogen to cereal crops. Global Change Biology 26: 191-199. https://doi.org/10.1111/gcb.14908 